\title{
多目的ダム事業における慣用的費用割振り法 の改善のためのゲーム論的考察
}

\author{
岡田憲夫 ${ }^{1} \cdot$ 谷本圭志 $^{2}$ \\ ${ }^{1}$ 正会員 工博 京都大学教授 防災研究所（干611 京都府宇治市五ケ庄） \\ ${ }^{2}$ 正会員 工修 三菱総合研究所（T100 東京都千代田区大手町二丁目3-6）
}

\begin{abstract}
多目的事業は複数の目的から成る共同事業であるため，共同事業費をいかに割り振るかという 「費用割り振り問題」を調整する必要がある。現在我が国に扔いて用いられている方法は，分離費用身 替り妥当支出法という慣用的な方法である。慣用法は実用性に長所がある反面，得られた解の理論的意 味づけが不明確であるとの短所を有する。一方近年の多目的ダム事業では, 社会的要請の変化に対して 新たな展開を求められている。本研究ではこのような新たな展開に対して, 慣用的な費用割り振り法が どこまで斉合性をもって適用可能かについての客観的基準の提案を試みる. おける費用割り振り法と慣用法との解の一致性に着目し，新たな一致性の特定を行った。
\end{abstract}

Key Words : game theory,multi-purpose reservoir,cost allocation,conflict analysis

\section{1.はじめに}

多目的ダム事業はより効率的，効果的な水管理を 推進することを目的として多くの流域で行われてき た. 当事業は複数の主体から成る共同事業であるた め, 共同事業費用を主体間でいかに割り振るかが重 要な現実的問題であり，これは「費用割振り問題」 と呼ばれる．本論文ではこの問題を以下の視点から 検討する.

我が国では米国のTVA事業の過程で開発された分 離費用残余便益法(Separable Costs Remaining Benefits Method,SCRB法) ${ }^{1)}$ に代表される慣用的な費用割振り 法にいくつかの補正を加えた分離費用身替り妥当支 出法が法制度化されて実用に供している。しかしな がら近年ではこの割振り法が制度化された当初に比 べて, 新たなダムサイトの適地が格段に減少すると ともに水源地対策の必要性が増大している. また, 余暇時間の増大や環境問題への関心の高まりを反映 して, 自然に恵まれたダム湖周辺のオープンスペー スをレクリエーションの場として積極的に利用すべ きとする社会的要請がある.このような新しい社会 的条件の下で, レクリエーションやその他の親水対 策を多目的ダムの新たな「目的」として加えてはど うかということが検討されるようになってきた。
現行の（慣用的）費用割振り法は，簡便性や理解 容易性といった実用的合理性に優れているため, 社 会的にその適用が受容されており，その有用性が実 証されている2)。しかし上述のようなダム事業の新 たな社会的要請とその対応に対してどこまで斉合性 をもって適用可能なのかについては十分な議論がな されていない，そこで本論文では，SCRB法に代表 される慣用法が，新たなタイプの目的の参入の下で， どこまで柔軟に対応し得るかについてその適用可能 範囲を検証，判定するための客観的基準を提案する ことを試みる. その際，理論的なベースとしてゲー ム理論を援用することとする.

\section{2.本論文の分析アプローチ}

慣用法を評価するアプローチとしては，いくつか の観点からの研究がなされているが，本論文では協 カゲームの理論において得られている公正配分解

(以下，ゲーム理論的費用割振り法と呼ぶ)に着目 する．費用割振り法を協力ゲーム理論の観点からア プローチした研究としては例えばSuzuki et $a l^{3)}$, Young $e t a l^{4)}$, Driesen $e t a l^{5}$, 森), 岡田 ${ }^{2)}$ な゙の研究 がある．岡田は特に慣用法を実用性の観点から基本 的に肯定する立場から，その理論的根拠の不備をゲ 
一ム理論や経済学の知見により補うための準拠枠を 構築することを目的として研究を展開している．本 論文ではその基本的立場を踏まえた上で新たに次の ような視点からの分析を試みる.

慣用法とゲーム理論的割振り法は互いに全く異なっ た領域で開発された経緯があり，割振り計算にも類 似性が認められないが，適当な条件が整うことによっ て，それらの割振り解が同值になるという一致性が 現れる7). 本論文ではこの二つの異なったアプロー チによる解の間の一致性に着目する. 即ち一致性が 認められるということは, 慣用法による割振り解に 自動的にダーム理論に基づく公正配分解としての意 味付けが与えられることを意味する．また一致性が 現れる範囲（一致性の条件）そのものが慣用法の適 用可能条件，即ちグーム理論的知見からみた妥当性 が保証される範囲を示すことになる. 本研究ではこ の一致性を慣用法の理論的意味付けと適用可能条件 を検証する上での重要かつ有効な特性として捉え, その特性を中心に議論を進めていくことにする.

慣用法とゲーム理論的費用割振り法との一致性の 条件はゲーム理論の知見として既に明らかになって いるものもある．本論文では更にこれらに加えて新 たな一致性の条件の導出を試みる。一致性の条件は 提携構造に関する費用関数の特性として規定される ので, これらはゲームの観点からみた費用関数の特 性（以後，グームの費用関数特性と呼ぶ）と何らか の関連性があると考えられる．ゲームの費用関数特 性としては劣加法性, Convex性, Semi-convex性,

One-convex性の条件を挙げることができる. そこで 本論文ではこれらの特性を取り上げ，一致性との関 連について理論的検討を行う.

次いで, 我が国の多目的ダム事業の実例からこれ らの特性に対応した費用関数形を特定する．このよ うな実証的な検討を踏まえて，多目的ダム事業の実 際的文脈において一致性が生じる，つまり慣用法に 理論的な意味づけがなされる可能性について検討す る.

\section{3.費用割振り法}

ここでは費用割振り法を，慣用法とゲーム理論的 費用割振り法に分類し，その主要な方法をTable 1 にまとめる.また，以下にその説明を加える.

\section{(1)慣用的費用割振り法}

慣用法はその簡便性から，各プロジェクトに適す る多くの方法が開発されてきた．多目的ダム事業に
Table 1 費用割振り法

\begin{tabular}{|l|l|}
\hline \multirow{4}{*}{ 慣用法 } & 身替り支出法 \\
\cline { 2 - 3 } & SCRB法 \\
\cline { 2 - 3 } & ENSC法 \\
\hline \multirow{4}{*}{$\begin{array}{c}\text { ゲーム理論的 } \\
\text { 方法 }\end{array}$} & 仁 \\
\cline { 2 - 3 } & 弱仁 \\
\cline { 2 - 3 } & 比例仁 \\
\cline { 2 - 3 } & 平均差仁 \\
\cline { 2 - 3 } & NSCG法 \\
\cline { 2 - 3 } & Shapley值 \\
\hline
\end{tabular}

おいても，事業を取りまく環境の変化の度に，その 改正，開発が行われてきた経緯がある ${ }^{28)}$. その結果, 現在我が国の多目的ダム事業ではSCRB法（の補正 版）が用いられている.SCRB法では，共通費用を 各主体が最低限負担すべき費用と，それを除いた事 業費の割振りとに分けて考える，すなわち，特定の 主体が最後に事業参加することによって生じる付加 的な費用増分である分離費用(separable costs)を，そ の発生責任者として当該の主体にそれを最低限の負 担額としてまず割り振る.次いで，残りの事業費

(非分離費用(non-separable cost)) を, 各主体に対し, その事業へのコミットメントの程度（を交渉力とし て表したもの）に応じて按分するという形をとる.

分離費用の概念を導入した方法の代表は，1930年 代のTVA(Tennesse Valley Authority)事業において提 案されたENSC法(Egalitarian Non-Separable Cost Method,均等配分型非分離費用法), ならびにこの SCRB法(Separable Costs,Remaining Benefits Method,分 離費用残余便益法) である ${ }^{1)}$. 本論文では慣用法とし てこのSCRB法, ENSC法を取り上げる.

なお，ゲーム理論的考察の関連性を説明するため の準備として，協力ゲーム理論の記号体系を用いな がらSCRB法とENSC法の概要について説明する.

多目的事業（全共同事業=全提携）に参加してい る主体（目的）の集合全体を $N=\{1,2, \cdots, n\}$ とする. 任意の主体を $i(\in N)$ で表し，それを要素とするNの 部分集合 $S(\subset N)$ を提携と呼ぶ. 任意の主体 $\{i\}$ を単独 (提携)，全主体の集合 $N$ を全提携と呼ぶ. 費用関 数を一般にC $C$ 表わす. 各主体が単独で事業を行い, 多目的ダム事業に参加した場合と同じ機能を達成す ることを想定した場合の費用は身替り費用と呼ばれ 
る.これは単独（提携）の費用 $C(\{i\})$ で表わされる

（以後簡単のためC $(i)$ と表わす）。これを提携Sによ る部分的共同事業に拡張した費用が $C(S)$ である.

ある主体 $i$ 分離費用 $S C_{i}$ は, 「全共同事業費用と, 任意の主体iを除いたすべての主体から構成される 共同事業費用との差」で定義されるので, 次式で表 わされる.

$$
S C_{i}=C(N)-C(N-\{i\})
$$

非分離費用NSC は分離費用を各主体に割り振った 後の共同事業の残余額と定義され, 次式で表わされ る.

$$
N S C=C(N)-\sum_{i \in N} S C_{i}
$$

\section{- SCRB法}

この方法では, 非分離費用は残余便益 $\min \{B(i)$, $C(i)\}-S C_{i}$ に比して割り振られる.ここに, $B(i)$ は経 済効果の面より主体价当該ダム計画に投資できる 金額の限度を示したもので，「妥当投資額」と呼ば れ，経済学的には，支払意志額とみなされる．残余 便益は当該主体の単独事業にかかる費用と, 共同事 業において当該主体に最低限配分されるべき費用, すなわち分離費用との差である. SCRB法では, そ の便益分だけ非分離費用(NSC)に対する負担のコミッ トメントが大きいとして, この值に応じて NSCを按 分して, 当該主体の負担分とする. すなわち, 共同 事業に参加することによって享受する費用割振りに 倸わる便益と解釈できる.SCRB法による主体に割 振り值 $x_{i}$ は,

$$
x_{i}=S C_{i}+\frac{\min \{C(i), B(i)\}-S C_{i}}{\sum_{j \in N}\left[\min \{C(j), B(j)\}-S C_{j}\right]} N S C
$$

である.ここに, $\sum_{i \in N} x_{i}=C(N)$ である. $B>C$ であれ ば, 上式は次式となる.

$$
x_{i}=S C_{i}+\frac{C(i)-S C_{i}}{\sum_{j \in N}\left\{C(j)-S C_{j}\right\}} N S C
$$

一般に $B>C$ であると考えて, 本論文では以後 SCRB法を式(4)の定義に限定して議論を進める.
- ENSC法

ENSC法では非分離費用を参加主体で均等に割り 振る. ENSC法による主体割振り值は次式で表わ される.

$$
x_{i}=S C_{i}+\frac{N S C}{n}
$$

この方法はTVA委員会で有力な方法として提案さ れたにもかかわらず最終的には不採用となった。こ れは非分離費用の均等割振りが必ずしも主体の立場 の違いを明確にしておらず，その意味で公平でない と考えられたからであろう。しかし実際には, 主体 間の「提携交涉可能性」の違いが費用算定上明確で ない場合や，それほど顕著でない場合が考えられる。 そのような場合は均等に割り振ることが逆に有効で あったりする，つまり，ENSC法は状況によっては その簡便性から, SCRB法より有用な費用割振り法 である可能性を十分に保持しており, 検討の対象に 值する慣用法である.

\section{(2)ゲーム理論的費用割振り法}

多目的ダム事業に参加するプレイヤー（目的，主 体）間に提携による協力関係が成立する場があると すると，費用割振り問題は協力ゲーム理論における 費用関数（または特性関数）によって規定される配 分(imputation)の問題に対応づけられる．ゲーム理論 における公正配分解の概念としてよく知れているの がコア (core $)^{9)}$ である.コアは割振り解が各主体の交 渉力の差異を提携の費用に求めた公正な解であり， かつ共同事業費用を効率的に割り振る配分の集合で ある.コアから唯一解を求める代表的な方法として 仁(Nucleolus)ならびに，その変種が提案されている. それらを以下に説明する。

$$
\text { ・仁 }{ }^{10), 11)}
$$

仁を求める際に用いられる基準が「不満」である. 任意の（実行可能な）割振り額が提示されたとき, 次式で表わされる割振り額ベクトル $X=\left(x_{1}, x_{2}, \cdots, x_{n}\right)$ に対する任意の提携 $S$ の不満 $e(X: S)$ の最大值を（辞書 式に）最小化したものが仁として定義される. 仁は, 最大不満の最小化を図ることによって公平性を保証 する解概念の一つである。

$$
e(X: S)=\sum_{i \in S} x_{i}-C(S)
$$

- 弱仁 $(\text { 平均仁 })^{4)}$ 
この方法では提携に関しての不満の代わりに，次 式で表わされる提携に参加している主体 1 人当たり の平均不満を考える.

$$
e(X: S) /|S|
$$

平均不満の最大值を最小化するような配分が弱仁 である.ここに|S|は，提携Sの構成員数を表わす。

- 相対仁

相対仁(Propensity to disrupt)は不満を提携間の「分 裂性向」（ある任意の提携 $S$ とその相手提携 $N-S$ と の不満比 ${ }^{* 1}$ ）として次式のように定義する.

$$
d(X: S)=\{-e(X: N-S)\}) /\{-e(X: S)\}
$$

「分裂性向」の最大值を最小化するような配分が 相対仁である. なお, 相対仁は以下の条件において 定義される.

$$
\sum_{i \in S} x_{i}<C(S) \quad(\forall S \subset N)
$$

コアに基づいた方法としてはこの他にも比例仁, 平均差仁がある. またコアに基づかないものとして は, 分離費用の概念を導入したNSCG法

(Non-separable Cost Gap Method, 非分離費用差法) シャプレイ值(Shapley value) ${ }^{13)}$ などがある.ここでは, NSCG法のみ簡単に説明しておく.

- NSCG法 ${ }^{5)}$

費用差関数 $g(S)$ を

$$
g(S)=C(S)-\sum_{j \in S} S C_{j}
$$

と定義する．一般に非分離費用 $N S C$ は全員提携Nの 費用差関数 $g(N)\left(=C(N)-\sum_{i \in N} S C_{i}\right)$ で定義されるが,

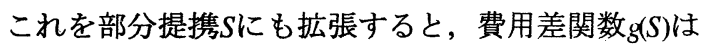
「部分提携 $S$ 非分離費用」と解釈できる.

費用差関数を用いて主体 $i$ の譲歩額 $\lambda_{i}$ を $\lambda_{i}=\min _{S \subseteq N}$ $g(S),(i \in S)$ と定義すると, NSCG法による主体iの分 担費用は次式で与えられる.

${ }^{{ }^{* 1}}$ 厳密には, 不満eにマイナスがついていることから 不満比というよりも剩余比として定義したものと解釈で きる.

$$
x_{i}=S C_{i}+\frac{\lambda_{i}}{\sum_{j \in N} \lambda_{j}} N S C
$$

この方法はENSC法やSCRB法を理論的に拡張した 方法になっている.

コアに基づかない方法については当然コアを充足 する保証は必ずしもない. また，コアに基づく方法 に比へてて割振り計算は容易であるが，いずれにして も慣用法に比べると計算上の煩雑性は否めない.

\section{4.慣用的費用割振り法のゲーム論的考察}

\section{(1)一致性についての既往の知見}

慣用法とゲーム理論的割振り法との一致性自体を 明示的に取り上げた研究はほとんど行われていない. ただし，新しい割振り法の開発の一環でSCRB法や ENSC法などの既存の慣用法との対応関係に言及し た研究がある. 例えぱDriesen,T.S.H. ${ }^{51}$ はNSCG法と SCRB法, NSCG法とENSC法との一致性について指 摘している. Heaney ${ }^{12)}$ はMCRS法(Marginal Costs Remaining Saving Method,限界費用残余便益法)と SCRB法, MCRS法とENSC法との一致性について触 れている.

鈴木 ${ }^{14)}$ は費用分担ゲームの解の特性という観点か ら一致性の可能性について述べているが，その条件 についての理論的な考察は行っていない. しかし鈴 木 ${ }^{15}$ は仁による割振り解が簡単な公式で表せる特殊 な条件を見いだしているため, 結果的にENSC法と 仁との一致性の条件を特定したことになる. 岡田 ${ }^{2)}$ は慣用法の再評価を行う過程でレビュー研究を行い, 慣用法としてSCRB法, ENSC法, ゲーム理論的割振 り法としてNSCG法, MCRS法を対象として, これ ら四種の費用割振り法の関係を明示している. 岡田 のレビュー研究ではその結果のみが示されているが, ここでは一致性の成立条件について少し詳しく紹介 しておこう。これは，(2)で述べる新たな一致性を検 討する上で，不可欠の知見となるからである. なお， 一致性の条件はNSCG法を考える際に用いた費用差 関数 $g(S)$ を用いて表わす.

(a)ENSC法とNSCG法

ENSC法とNSCG法に関する一致性の十分条件は 次式で表わされる5).

$$
g(S) \geq g(N) \quad(\forall S \subset N)
$$


この条件は，任意の提携Sに関する費用差関数の 最小值が全提携 $N$ に関する $g(N)$ であることを示す． このとき譲歩額は $\lambda_{i}=g(N)=N S C$ である. よって $\lambda_{i} /$ $\sum_{j} \lambda_{j}=1 / n$ であり, NSCG法はENSC法と一致する.

\section{(b)SCRB法とNSCG法}

SCRB法とNSCG法に関する一致性の十分条件は 次式で表わされる .

$$
g(S) \geq g(i) \quad(\forall i \in S \subset N)
$$

この条件は単独提携 $\{i\}(\forall i \in S)$ の $(i)$ は $g(S)$ の最小 值であることを示す.このとき, 譲歩額 $\lambda_{i}=C(i)-$ $S C_{i}$ となり, 式(4)に示す $S C R B$ 法と同值である.

(a), (b)より, 費用差関数の最小值が最大規模の提 携 $N$, または最小規模の提携 $\{i\}$ に対応すれば, NSC G法はそれぞれENSC法, SCRB法と一致する.

コアに基づく費用割振り法である仁，及びその変 種はNSCG法とは違い, ENSC法やSCRB法の拡張概 念とはなっていない. しかしこの一見したところ一 致性など予想できない両方法間に，ある適当な条件 が整うことによって，一致性が成立する事実がゲー ム理論の知見として得られている. それは先述した ように仁とENSC法の一致性である ${ }^{(4)}$. この一致性 の十分条件は以下のように示される。

(c)ENSC法と仁

$$
g(S) \geq \frac{|S|+1}{n} g(N) \quad(\forall S \subset N)
$$

この条件は(a),(b)と比べると幾分複雑になってい る.この条件式は，提携Sの非分離費用が満たす心 き条件が提携の規模の増大に伴って厳しくなること を示している.またこの条件は， $g(S) \geq g(N)$ であれ ば十分であることに留意したい.

\section{(2)新たな一致性の条件の提示}

本論文では(1)で言及した既往の知見を踏まえた上 で，慣用法が（暗に）備えている理論的根拠の可能 性をより多様に見い出すために, 新たな一致性の導 出を試みる.すなわち, ENSC法と弱仁の一致性, 並びにSCRB法と相対仁との一致性の条件を特定す る.

(d)ENSC法と弱仁

ENSC法と弱仁に関する一致性の十分条件は次式
に示される.また(3)で示すように, この条件の下で これらの割振り解が一意的に一致することが理論的 に証明できる.

$$
g(S) \geq \frac{|S|}{n-1} g(N) \quad(\forall S \subset N)
$$

この条件は仁とENSC法との一致性の条件である 式(14)に類似している. また $n \geq|S|+1$ が成立するた め, 式(14)は式(15)の十分条件である. よって，仁と ENSC法の解が二致している場合, 同時に弱仁もそ れらに一致していることになる. 式(15)は式(14)と同 様, 任意の提携Sの非分離費用が満たすべき条件が 提携の規模の増大に伴って厳しくなることを示して いる. しかしこの条件は式(14)と比べると緩い条件 であることから，一致性が生じる範囲はその分広く なると言える．またこの条件についても式(14)と同 様に, $g(S) \geq g(N)$ であれぱ十分である.このことは 後述するゲームの費用関数特性と関連性があると考 えられる.

(e)SCRB法と相対仁

非分離費用 $(N S C=g(N))$ が非負, かつ強劣加法性 （この性質については付録参照）を仮定する．その 下で, SCRB法と相対仁に関する一致性の十分条件 は次式に示される。この証明は(3)に譲る。

$$
\text { i) } g(S) \geq \alpha_{S} g(N) \quad(\forall S \subset N)
$$

または, ii) $g(S) \leq \alpha_{S} g(N) \quad(\forall S \subset N)$

$$
\text { ここに, }
$$

$$
\alpha_{S}=1-\frac{\sum_{i \in N-S} g(i)-g(N-S)}{\sum_{i \in N} g(i)-g(N)}
$$

である．SCRB法と相対仁に関する一致性の十分条 件は式(16),(17)に示すように二つ存在する.これら 二つの条件式に関して注意すべきことは，任意の費 用関数の下に，「ある提携については式(16), 別の 提携については式(17)が成立」していることがSCRB 法と相対仁による解が一致する条件ではないという ことである，一致性が成立するためには，「任意の 提携に対して式(16)が成立」するか，「任意の提携 に対して式(17)が成立」している場合のいずれかで ある. また当然のことながら，これら二つの条件が 同時に満たされることはない. 
SCRB法と相対仁の一致性に関して特筆すべきこ とは，三人ゲーム以下ではNSC >0かつ強劣加法性 の下で, 式(16), もしくは式(17)のいずれかが必ず満 たされるため, この一致性は常に成立するという点 である.これについての理論的証明は次節に示す.

一致性成立の条件である強劣加法性から $\alpha_{s} \leq 1$ で ある.これより, 式(16)は $g(S) \geq g(N)$ であれば十分で ある. また, 式 $(17)$ は $g(S) \leq g(N)$ が必要条件である.

このように, 既往の知見及び本論文で特定した一 致性の条件は費用（差）関数の条件によって表わさ れる. 従って, 一致性の条件はゲームの費用関数特 性と密接な関連があることが推察される.この点に ついての検討は(4)で行う。

\section{(3)一致性の証明}

前節で得られた一致性の証明を以下に行う。

a)ENSC法と弱仁の一致性の証明

$$
g(S) \geq \frac{|S|}{n-1} g(N)(\forall S \subset N)
$$

費用割振り法を式(19)とする時, 費用差関数 $g(S)$ に上の条件が成立していれば，Xは弱仁に なる。

$$
x_{i}=S C_{i}+\frac{1}{n} g(N)
$$

\section{【証明】}

$Z$ Z $Z$ $X$ なる任意の割振り額べクトルとすると， $z_{i}<x_{i}$ となるiがあるので，提携 $N-\{i\} に つ い て ，$

$$
\begin{aligned}
& \frac{\sum_{j \in N-\{i\}} z_{j}-C(N-\{i\})}{n-1}=\frac{S C_{i}-z_{i}}{n-1}>\frac{S C_{i}-x_{i}}{n-1} \\
= & -\frac{g(N)}{n(n-1)}=\frac{g(N)}{n}-\frac{g(N)}{(n-1)} \geq \frac{\frac{|S|}{n} g(N)}{|S|}-\frac{g(S)}{|S|} \\
= & \frac{-g(S)+\frac{|S|}{n} g(N)}{|S|}=\frac{\sum_{i \in S} x_{i}-C(S)}{|S|}
\end{aligned}
$$

よって, Xは弱仁である.

ここで, (15)の条件式において，任意の提携 $S に N$ が含まれない理由について触れておく，仮にSにNが
含まれるとすると, 式(20)の最右辺においてNの (平均) 不満を考えることになる．しかし「Nの不 満」は定義されていないため, SにNを含めるのは適 切ではない.このことは, 式(14),(16),(17)について も同様である。

b)SCRB法と相対仁の一致性の証明

$$
\text { i) } g(S) \geq \alpha_{s} g(N) \quad(\forall S \subset N)
$$

または, $\quad$ ii) $g(S) \leq \alpha_{S} \mathrm{~g}(N) \quad(\forall S \subset N)$

$$
\alpha_{S}=1-\frac{\sum_{i \in N-S} g(i)-g(N-S)}{\sum_{i \in N} g(i)-g(N)}
$$

ここで, $h(S)$ を次のように定義する.

$$
h(S)=\sum_{i \in S} g(i)-g(S)
$$

強劣加法性の下では, $h(N)>0$ である. 上の一致 性の条件i),ii)はそれぞれ，次式のように表わされる. ただし，ii)については， $S$ と $S$ をを置き換えている.

$$
\text { i)' } g(S) \geq \frac{h(N)-h(N-S)}{h(N)} g(N) \quad(\forall S \subset N)
$$

または, ii)' $g(N-S) \leq \frac{h(N)-h(S)}{h(N)} g(N)(\forall S \subset N)$

費用割振り法を式(22)とする時, 非分離費用 $g(N)$ の非負条件 $g(N)>0$ 及び強劣加法性の下に, 条件i), もしくはii)が成立すると，Xは相対仁 になる。

$$
x_{i}=S C_{i}+\frac{g(i)}{\sum_{j \in N} g(j)} g(N)
$$

また式(9)より，次式が成立する．

$$
g(S) h(N)>h(S) g(N)
$$

【条件i)に関する証明】

$Z$ $Z \neq X$ なる任意の割振り額ベクトルとすると， 


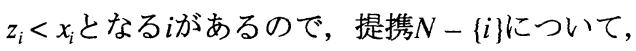

$$
\begin{aligned}
= & \frac{g(i)-\frac{g(i)}{\sum_{j \in N} g(j)} g(N)}{\frac{g(i)}{\sum_{j \in N} g(j)} g(N)}=\frac{\sum_{j \in N} g(j)-g(N)}{g(N)} \\
= & \frac{h(N)}{g(N)}
\end{aligned}
$$

ここで条件i)'を変形すると, 次式を直ちに得る.

$$
\begin{array}{r}
h(N) \frac{g(S)}{g(N)}-h(S) \geq h(N)-h(N-S)-h(S) \\
-g(N)+g(N-S)+g(S) \geq g(N-S)-\frac{h(N-S)}{h(N)} g(N)
\end{array}
$$

ここで $h(S), g(S)$ の定義より，次式が成立する．

$$
-g(N)+g(S)+g(N-S)=h(N)-h(S)-h(N-S)
$$

よって式(25)に式(27)を代入すると，

$$
h(N) \frac{g(S)}{g(N)}-h(S) \geq-g(N)+g(N-S)+g(S)
$$

式(26),(28)より,

$$
h(N) \frac{g(S)}{g(N)}-h(S) \geq g(N-S)-\frac{h(N-S)}{h(N)} g(N)
$$

従って, 次式が成立する.

$$
\frac{h(N)}{g(N)} \geq \frac{g(N-S)-\frac{h(N-S)}{h(N)} g(N)}{g(S)-\frac{h(S)}{h(N)} g(N)}
$$

ところで,

$$
\begin{aligned}
& \frac{C(N-S)-\sum_{j \in N-S} x_{j}}{C(S)-\sum_{j \in S} x_{j}}=\frac{g(N-S)-\frac{\sum_{j \in N-S} g(j)}{\sum_{j \in N} g(j)} g(N)}{g(S)-\frac{\sum_{j \in S} g(j)}{\sum_{j \in N} g(j)} g(N)} \\
& =\frac{g(N-S)(h(N)+g(N))-(h(N-S)+g(N-S)) g(N)}{g(S)(h(N)+g(N))-(h(S)+g(S)) g(N)} \\
& =\frac{g(N-S)-\frac{h(N-S)}{h(N)} g(N)}{g(S)-\frac{h(S)}{h(N)} g(N)}
\end{aligned}
$$

であるから，式(24),(30),(31)より，

$$
\frac{C(i)-z_{i}}{C(N-\{i\})-\sum_{j \in N-\{i\}} z_{j}}>\frac{C(N-S)-\sum_{j \in N-S} x_{j}}{C(S)-\sum_{j \in S} x_{j}}
$$

となり，Xは相対仁である.

\section{【条件ii)に関する証明】}

$Z$ Z $Z \neq X$ なる任意の割振り額べクトルとすると,

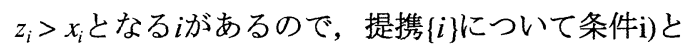
同様にして次式を得る.

$$
\frac{C(N-\{i\})-\sum_{j \in N-\{i\}} z_{j}}{C(i)-z_{i}}>\frac{g(N)}{h(N)}
$$

ところで条件ii)'より直ちに次式を得る.

$$
g(S)-\frac{h(S)}{h(N)} g(N) \geq-g(N)+g(S)+g(N-S)
$$

$$
h(N)-h(S)-h(N-S) \geq \frac{g(N-S)}{g(N)} h(N)-h(N-S)
$$

である. 式(27)より, 式(33)は次式と同等である.

$$
g(S)-\frac{h(S)}{h(N)} g(N) \geq h(N)-h(S)-h(N-S)
$$

式(34),(35)より, 次式が成立する. 


$$
g(S)-\frac{h(S)}{h(N)} g(N) \geq \frac{g(N-S)}{g(N)} h(N)-h(N-S)
$$

従って, 次式が成立する.

$$
\frac{g(N)}{h(N)} \geq \frac{g(N-S)-\frac{h(N-S)}{h(N)} g(N)}{g(S)-\frac{h(S)}{h(N)} g(N)}
$$

式(31)と同様の変形を行えば,

$$
\frac{C(N-S)-\sum_{j \in N-S} x_{j}}{C(S)-\sum_{j \in S} x_{j}}=\frac{g(N-S)-\frac{h(N-S)}{h(N)} g(N)}{g(S)-\frac{h(S)}{h(N)} g(N)}
$$

よって, 式(32),(37),(38)より,

$$
\frac{C(N-\{i\})-\sum_{j \in N-\{i\}} z_{j}}{C(i)-z_{i}}>\frac{C(N-S)-\sum_{j \in N-S} x_{j}}{C(S)-\sum_{j \in S} x_{j}}
$$

となる.よって，Xは相対仁である.

c)三人ゲームにおけるSCRB法と相対仁との一致 性

以下に，三人ゲームにおいてSCRB法と相対仁が 常に成立することを示す.

\section{【証明】}

任意の提携 $N-\{i\}$ に対して費用差関数の定義より，

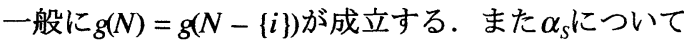
も，提携 $N-\{i\} に$ 対して $\alpha_{s}=1$ となる.よって，三 人ゲームにおける任意の二人提携については，式 (16)(17)共に満たされる.

任意の単独提携 $S=\{i\}$ については, 以下の場合に 応じて式(16)，もしくは式(17)が成立する.

$$
\text { i) } 2 g(N) \geq \sum_{i \in N} g(i)
$$

条件i)は強劣加法性及び非分離費用が非負との仮 定の下で，以下の式に変形できる.

$$
\begin{aligned}
& g(N) \geq \sum_{i \in N} g(i)-g(N) \\
& \frac{1}{g(N)} \leq \frac{1}{\sum_{i \in N} g(i)-g(N)}
\end{aligned}
$$

ここで, $g(i)=g(i)+g(N-\{i\})-g(N)$ が成り立つの で, 次式が成立する.

$$
\frac{g(i)}{g(N)} \leq \frac{g(i)+g(N-\{i\})-g(N)}{\sum_{i \in N} g(i)-g(N)}=\alpha_{S}
$$

上式は，条件i)の成立下では任意の単独提携に対 して式(16)が成立することを表わしている.

ii) $2 g(N) \leq \sum_{i \in N} g(i)$

i)と同様に条件ii)の成立下では任意の単独提携に 対して式(17)が成立する.

以上より，三人ゲームにおける任意の提携に対し て式(16),(17)のいずれか一式が成立し，常に一致性 が生じることが証明された。

\section{(4)一致性の条件とゲームの費用関数特性との関連}

一般に, 共同事業に参加するにはそれ相応の経済 的なメリットが保証される必要がある。このことは 費用割振りグームの費用関数の特性（あるいは節約 額分担ゲームの特性関数での特性）と密接な関連が あると考えられる. この点についてDriesen et $^{1 l^{16) 17)}}$ や, 岡田 ${ }^{18)}$ は提携構造と費用関数特性との関連性に 着目して分析を行っている.ここでは簡単にこれら の基本的特性を整理した上で，一致性が生じる範囲 を規定する基本的な要件を明らかにする，なお，各 ゲームの費用関数特性の詳細ついては，付録を参照 されたい.

一致性の条件を費用関数特性に関連づけると, SCRB法とNSCG法, 並びにENSC法とNSCG法との 一致性の条件はそれぞれSemi-convex性, One-convex 性の条件式そのものであることが判る.

ENSC法と仁，及びENSC法と弱仁の一致性は，い ずれもOne-convex性を十分条件とする.これは,

$$
g(N) \geq \frac{|S|+1}{n} g(N) \geq \frac{|S|}{n-1} g(N)
$$

が成立するからである.

SCRB法と相対仁との一致性式(16)については式 
Table 2 一致性とゲームの費用関数特性

(網かけ部は本論文で特定した一致性を示す)

\begin{tabular}{|c|c|}
\hline ゲームの費用関数特性 & 一致性 \\
\hline Weak-convex性 & SCRB $=$ 相対 \\
\hline Semi-convex性 & SCRB=NSCG（十分） \\
\hline \multirow[t]{4}{*}{ One-convex性 } & $\mathrm{SCRB}=$ 相洸 1 ( $(1 / \mathrm{J})$ \\
\hline & 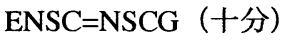 \\
\hline & $\mathrm{ENSC}=$ 仁（十分） \\
\hline & $\mathrm{ENSC}=$ 弱 $(1,0)$ \\
\hline
\end{tabular}

(28)が満たされていれば十分である.これは， $\alpha_{s} \leq 1$ が成立するので次式を得るからである.

$$
g(N) \geq \alpha_{s} g(N)
$$

従ってSCRB法と相対仁に対する一致性の条件式 式(16)については, One-convex性が満たされていれ ば十分である．同様に式(17)の必要条件は $g(S) \leq g(N)$ である。ここではこの条件をWeak- convex性と定義 する. 従って, SCRB法と相対仁はWeak-convex性か らOne-convex性にわたる広い範囲で一致性が生じる 可能性が高いと言えよう.

ゲームの費用関数特性と前節で得られた一致性の 条件とを関連づけた結果を整理してTable 2に示す. なお表中の各行の（）の中の「必要」または「十 分」は，その行に示すゲームの費用関数特性が一致 性に対して必要条件か十分条件かを示したものであ る.これより，一致性が生じる基本的要件がゲーム の費用関数特性であることが具体的に理解できよう. また, Weak-convex性及びSemi- convex性の部分集合 がConvex性であることから, Convex性の成立下では SCRB法, One-convex性の成立下ではENSC法による 解にゲーム理論的な意味付けができると考えられる.

またここでSCRB と相対仁が一致するケースは, 先述したように，排反する式(16)，(17)のいずれかの 場合に対応している. 従って, One-convex性が Weak-convex性の部分集合となることを意味するも のではないことを断っておこう.

慣用法とダーム理論的割振り法による割振り解の 一致性を, 三人ゲーム $(N=\{1,2,3\})$ を例としてTable 3,Table 4に示す. ただし, $C(\{i, .\}$.$) を C(i, .$.$) と示す.$ $g(・)$ にいても同様である. 表中において, 同じ網 かけパターンで示されている割振り法の解の間に一 致性が生じている.

Table 3.1では，SCRB法とNSCG法，SCRB法と
相対仁, ENSC法と弱仁がそれぞれ一致している. これらの一致性を各条件式（式(12) (17)）に照らし あわせて検証してみよう。費用差関数がTable 3.2 のように計算される.これよりConvex性が成立して いることが判る. またTable 3.3では, 式(13)につ いては $\{i\} に ， そ れ 以$ 外の式にはS S任意の(適当な)提 携を代入した場合に当条件式における左辺と右辺の 大小関係が成立するかどうかを確認することができ る.ただし, 任意のiに対して $g(N)=g(N-\{i\})$ が成立 することから任意の二人提携を $N-\{i\}$ と表わす.こ こでは，一致性が成立している条件式のみを示して

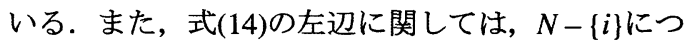
いてのみ考慮すれば十分であることから，それのみ を考慮している.

Table 4.1〜3はOne-convex性が成立する場合の一 致性の例である. One-convex性の成立下ではENSC 法と仁，弱仁，NSCG法の間で一致性が成立するこ とが先の理論的検討によって明らかにされているが, そのことがTable 4.3において確認できる.このよ うな一致性の成立は, 偶発的に生じたのではなく, 上記のような条件が成立する場合には必ず一致する という点が重要である.このような条件を理論的に 特定しておくことの有効性は正にこの点にある.

本章ではConvex性, One-convex性などのゲームの 費用関数特性の成立が一致性が生じるための基本的 な要件であり, その下で慣用法にゲーム理論的な意 味付けがなされることが判明した. さて, 実際の多 目的ダム事業において，これらの特性の成立可能性 は保証されるのであろうか. 次章では今までの理論 的展開を多目的ダムの実際的文脈において解釈して いこう.

\section{5.実際の多目的ダム事業での検討}

我が国の多目的ダム事業では身替り費用は身替り ダムの容量から，また分離費用は分離容量を勘案し て算定される．このように実際のダム事業の費用は 貯水容量を基準に決定されている．貯水容量をべー スとする費用関数は，任意の主体が事業に参加する 際に積み増す必要容量に対して, 限界費用も積み増 すことによって特定される曲線である。ここで, ゲ 一ムの費用関数特性が付録の式(A.7),(A.9), (A.11), (A.13)に示しているように, 任意の主体の参加に対 する限界費用で表わされる，従って，貯水容量に対 する限界費用の変化のパターンとゲームの費用関数 特性には何らかの対応関係が特定できるであろう.

我が国の事例では，容量に対して費用が违減する 
Table 3.1 割振り解の一致性（1）

\begin{tabular}{|c|c|c|c|}
\hline & $x_{1}$ & $x_{2}$ & $x_{3}$ \\
\hline SCRB法 & 6.1 & 5.1 & 4.8 \\
\hline 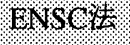 & 56 & $4: 1$ & 6. \\
\hline 仁 & 6.0 & 5.0 & 5.0 \\
\hline 47 & $5.6 \%$ & 4. & 6 \\
\hline 相対伴 & 6.1 & 5.1 & 4.8 \\
\hline NSCG法 & 6.1 & 5.1 & 4.8 \\
\hline
\end{tabular}

$$
\begin{gathered}
C(1)=10 \quad C(2)=9 \quad C(3)=7 \\
C(1,2)=13 \quad C(1,3)=14 \quad C(2,3)=13 \\
C(N)=16
\end{gathered}
$$

Table 3.2 費用差関数（1）

\begin{tabular}{|c|c|c|c|c|}
\hline \multicolumn{5}{|c|}{$g(S) \geq g(i)$} \\
\hline$\{i\}$ & $\{1\}$ & $\{2\}$ & $\{3\}$ & - \\
\hline 左辺 & 8 & 8 & 8 & - \\
\hline 右辺 & 7 & 7 & 4 & - \\
\hline \multicolumn{5}{|c|}{ 式(14) } \\
\hline$\{S\}$ & $\{1\}$ & $\{2\}$ & $\{3\}$ & $N-\{i\}$ \\
\hline 左辺 & 8 & 7 & 7 & 4 \\
\hline 右辺 & 8 & 4 & 4 & 4 \\
\hline \multicolumn{5}{|c|}{ 式(16) $\quad g(S) \geq \alpha_{S} g(N)$} \\
\hline$\{S\}$ & $\{1\}$ & $\{2\}$ & $\{3\}$ & $N-\{i\}$ \\
\hline 左辺 & 8 & 7 & 7 & 4 \\
\hline 右辺 & 8 & $28 / 5$ & $28 / 5$ & $16 / 5$ \\
\hline
\end{tabular}

$$
\begin{gathered}
g(1)=7 \quad g(2)=7 \quad g(3)=4 \\
g(1,2)=g(1,3)=g(2,3)=8 \\
g(N)=8
\end{gathered}
$$

Table 3.3 一致性の条件（1）

ような曲線が得られることが多い.しかし，ダムの 地理的条件やその他の諸条件, 及び事業に参加する 主体の性格によって曲線（費用関数）の特性が微妙 に異なる可能性もある.

\begin{tabular}{|c|c|c|c|}
\hline & $x_{1}$ & $x_{2}$ & $x_{3}$ \\
\hline SCRB法 & 7.8 & 4.7 & 3.5 \\
\hline GNSC & 17 & 4.7 & $1 \%$ \\
\hline V. & $7 \%$ & 4.1 & . \\
\hline 65 & 17 & $4 \%$ & 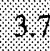 \\
\hline 相対侣 & 7.8 & 4.7 & 3.5 \\
\hline NSOCH & $1 \%$ & 4.7 & 3. \\
\hline
\end{tabular}

以下では，我が国の実際の多目的ダム事業から （貯水容量に対する費用の曲線として）得られた費 用関数の事例を紹介し，以下にその説明を加える. それと同時に，費用割振り法間の一致性を記す。な
Table 4.1 割振り解の一致性（2）

$$
\begin{gathered}
C(1)=12 \quad C(2)=8 \quad C(3)=6 \\
C(1,2)=13 \quad C(1,3)=12 \quad C(2,3)=9 \\
C(N)=16
\end{gathered}
$$

Table 4.2 費用差関数（2）

$$
\begin{gathered}
g(1)=5 \quad g(2)=4 \quad g(3)=3 \\
g(1,2)=g(1,3)=g(2,3)=2 \\
g(N)=2
\end{gathered}
$$

Table 4.3 一致性の条件（2）

\begin{tabular}{|c|c|c|c|c|}
\hline \multicolumn{5}{|c|}{ 式(12) } \\
\hline$\{S\}$ & $\{1\}$ & $\{2\}$ & $\{3\}$ & $N-\{i\}$ \\
\hline 左辺 & 2 & 5 & 4 & 3 \\
\hline 右辺 & 2 & 2 & 2 & 2 \\
\hline 式(14) & \multicolumn{5}{|c|}{$g(S) \geq(\{|S|+1\} / n) g(N)$} \\
\hline$\{S\}$ & $\{1\}$ & $\{2\}$ & $\{3\}$ & $N-\{i\}$ \\
\hline 左辺 & 2 & 5 & 4 & 3 \\
\hline 右辺 & 2 & $4 / 3$ & $4 / 3$ & $4 / 3$ \\
\hline 式(15) & $g(S) \geq(I S \mid /(n-1))$ & $g(N)$ \\
\hline$\{S\}$ & $\{1\}$ & $\{2\}$ & $\{3\}$ & $N-\{i\}$ \\
\hline 左辺 & 2 & 5 & 4 & 3 \\
\hline 右辺 & 2 & $2 / 3$ & $2 / 3$ & $2 / 3$ \\
\hline \multicolumn{5}{|c|}{ 式(16) } \\
\hline$\{S\}$ & $\{1\}$ & $\{2\}$ & $\{3\}$ & $N-\{i\}$ \\
\hline 左辺 & 8 & 7 & 7 & 4 \\
\hline 右辺 & 8 & $28 / 5$ & $28 / 5$ & $16 / 5$ \\
\hline
\end{tabular}

お，これらの事例は佐々木7)の研究より引用した。

Fig.1.1は静岡県の長島ダムの費用関数である. 


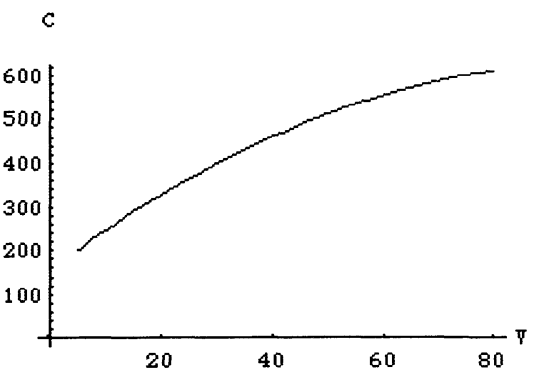

Fig.1.1 長島ダムの費用関数

Table 5.1(a) 長島ダムでの各主体の 費用及び貯水容量

\begin{tabular}{|c|c|c|c|c|c|c|c|}
\hline & F & A & W & FA & FW & AW & FAW \\
\hline $\begin{array}{c}\text { COST } \\
\text { (億円) }\end{array}$ & 561 & 201 & 393 & 571 & 601 & 410 & 610 \\
\hline $\begin{array}{c}\text { VOLUME } \\
\text { (百万 } \mathrm{m}^{3} \text { ) }\end{array}$ & 63 & 5 & 29 & 66 & 75 & 32 & 78 \\
\hline
\end{tabular}

F..洪水制御 A..農業用水 W..都市用水

Table 5.1(b) 長島ダムでの割振り解の一致性

\begin{tabular}{|c|c|c|c|c|}
\hline & 仁 & 弱仁 & 相対仁 & NSCG法 \\
\hline SCRB法 & - & - & $\bigcirc$ & $\bigcirc$ \\
\hline ENSC法 & $\times$ & $\bigcirc$ & - & $\times$ \\
\hline
\end{tabular}

○..一致する $\times$.. 一致しない

$\triangle$..ほぼ一致する -..一致性が想定し得ない

長島ダムにおける任意の提携の費用及び貯水容量を

Table 5.1(a)に示す．なお，F,FA,..は各主体による 提携を表わしている.

Fig.1.1は貯水容量の増加に対する費用は単調増 加している.これに対して費用関数の数值を用いる と, 実際にConvex性が成立していることが判る.こ のときの費用配分結果をTable 5.1(b)に記す． 4.で 導出した理論的知見から容易に予測されるように, SCRB法とNSCG法, SCRB法と相対仁及び, ENSC 法と弱仁の割振り解の值が一致している.

Fig.1.2は杤木県の川治ダムの費用関数である. 川治ダムにおける任意の提携の費用及び貯水容量を Table 5.2(a)に示す.この例では, 60 (百万 $\mathrm{m}^{3}$ ) 付近 に若干の費用の急増が認められるが，全般的にほぼ 容量Vに対して単調増加していると見なせる．ゲー ムの費用関数特性を計算でチェックすると, 一部の 提携に対してConvex性の条件式が成立していないが, 数值的にその差は僅かであり,ほぼConvex性が成立 していることが示される. Table 5.2(b)によると，

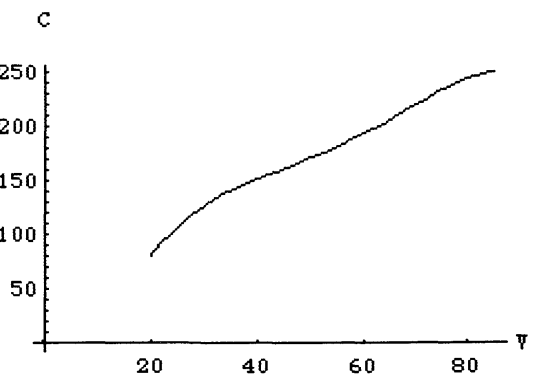

Fig.1.2川治ダムの費用関数

Table 5.2(a) 川治ダムでの各主体の 費用及び貯水容量

\begin{tabular}{|c|c|c|c|c|c|c|c|}
\hline & F & A & W & FA & FW & AW & FAW \\
\hline $\begin{array}{c}\text { COST } \\
\text { (億円) }\end{array}$ & 164 & 130 & 185 & 199 & 214 & 242 & 250 \\
\hline $\begin{array}{c}\text { VOLUME } \\
\text { (百万 } \mathrm{m}^{3} \text { ) }\end{array}$ & 46 & 31 & 55 & 62 & 68 & 79 & 83 \\
\hline
\end{tabular}

F..洪水制御 A..農業用水 W..都市用水

Table 5.2(b) 川治ダムでの割振り解の一致性

\begin{tabular}{|c|c|c|c|c|}
\hline & 仁 & 弱仁 & 相対仁 & NSCG法 \\
\hline SCRB法 & - & - & $\bigcirc$ & $\triangle$ \\
\hline ENSC法 & $\times$ & $\bigcirc$ & - & $\times$ \\
\hline \multicolumn{2}{|c|}{ O.-致する } & \multicolumn{4}{c|}{$\times$ 一致しない }
\end{tabular}

$\triangle$..ほぼ一致する -..一致性が想定し得ない

SCRB法と相対仁，及びENSC法と弱仁が一致してい る. また, SCRB法とNSCG法の厳密な一致性は生 じていないが, 各々の割振り解はかなり近いものと なっていることが判る（Table 5.2(b)において 評価している）. また他のいくつかのダムについて も文献 ${ }^{19}$ で調べることができる.

従って，我が国の多目的ダム事業における現実の 費用関数には概ねConvex性が成立する可能性が高い ことが推定される.よって我が国の多目的ダム事業 ではSCRB法とNSCG法, SCRB法と相対仁との一致 が多くの場合期待できる.

一方, One-convex性の成立事例は現在のところほ とんどない。しかし, 谷本 ${ }^{201}$ は親水目的が新たに多 目的ダム事業に参加することを想定したケーススタ ディーにおいて, One-convex性の成立可能性につい て言及している．この検討で得られている費用関数 と, 一致性をFig.2,Table 6.1(a),(b)に示す.この 費用関数にOne-convex性そのものは成立していない ものの, その成立にかなり近い状況であることがわ 
C

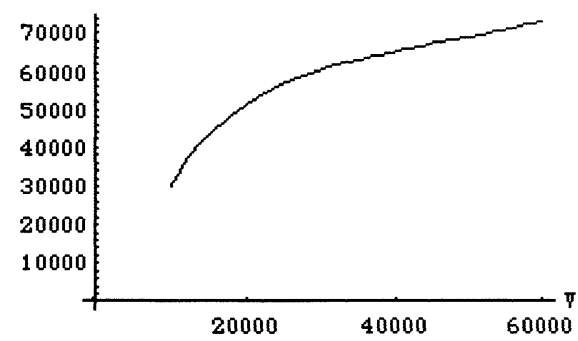

Fig.2 One-convex性に近い状況を呈する

費用関数

Table 6.1(a) Fig.2での各主体の 費用及び貯水容量

\begin{tabular}{|c|c|c|c|c|c|c|c|}
\hline & F & W & E & FW & FE & WE & FWE \\
\hline $\begin{array}{c}\text { COST } \\
\text { (億円 })\end{array}$ & 602 & 494 & 611 & 625 & 674 & 647 & 704 \\
\hline $\begin{array}{c}\text { VOLUME } \\
\text { (百万 } \mathrm{m}^{3} \text { ) }\end{array}$ & 24 & 18 & 28 & 33 & 49 & 37 & 58 \\
\hline
\end{tabular}

F..河川 W..上水道 $\mathrm{E}$..親水

Table 6.1(b) Fig.2での割振り解の一致性

\begin{tabular}{|c|c|c|c|c|}
\hline & 仁 & 弱仁 & 相対仁 & NSCG法 \\
\hline SCRB法 & - & - & $\bigcirc$ & $\times$ \\
\hline ENSC法 & $\bigcirc$ & $\bigcirc$ & - & $\times$ \\
\hline
\end{tabular}

$\triangle$..ほぼ一致する -..一致性が想定し得ない

かる. すなわち, Table 5.1(b), Table 5.2 (b)では, ENSC法と弱仁との一致性は成立しているが， ENSC 法と仁との一致性は認められない。これは式(41)か らわかるように, Table 5.1(b),Table 5.2 (b)の状 況よりも，Table 6.1(b)に示す情報のほうが，より One-convex性に近い状況にあると判断し得るからで ある.このときの費用関数は, 親水目的の参加によっ て增大した水没補償費用に伴い, 全提携Nに関する 貯水容量付近で費用が若干ながら急増している. よっ て, One-convex性は, 比較的大きい貯水容量規模に おいて費用が急増している費用関数において，その 成立が認め得ると考えられる.

以上の事例より, Convex性やOne-convex性といっ たゲームの費用関数特性が（貯水容量に対する）費 用関数の費用の急増，すなわち費用関数の傾きによっ て規定されることがわかる.

\section{6.結論}

本論文では，多目的ダム事業において従来から広 く用いられてきた慣用的費用割振り法を取り上げ， その欠点である理論的妥当性の判定条件の欠如を補 うことを目的とした。即ち，理論的な適用可能条件 を特定するために，仁などのゲーム理論に基づく公 正配分解との関連性について検討を行った. その際, 適用可能の規定条件を慣用的費用割振り法とグーム 理論に基づく費用割振り法との一致性の条件に求め た.

具体的には, ENSC法と仁の一致性等の既往の知 見を整理するとともに，さらに

・ ENSC法と弱仁の一致性

- SCRB法と相対仁の一致性

の条件を新たに特定した.SCRB法と相対仁の一 致性の条件は二つ存在するが，三人ゲームにおいて はこれらの解が一意的に一致することが明らかになっ た.

次いで，これらの一致性をConvex性等のゲームの 費用関数特性と関連づけることにより，一致性の条 件が示す基本的な要件を明らかにした。ここでは, One-convex性が成立する範囲では, ENSC法, 仁, 弱仁, NSCG法の四方法が同時に一致するという知 見を得た。

最後に我が国の多目的ダム事業の実例に即して, 貯水容量配分をべースにして特定される費用関数が Convex性を充足する傾向が強いことに着目した。 も しこのことが費用関数の構造特性上より一般的, 理 論的に裏付けられれば，現行の費用割振り法である SCRB法にはNSCG法と相対仁の理論的意味付けが 保証されるであろう。少なくとも現時点では慣用的 費用割振り法は多目的ダム事業の実際的な文脈にお いて十分理論的妥当性を有している状況証拠がある と判断される.またOne-convex性が成立する場合は ENSC法にもNSCG法, 仁法, 弱仁法としての理論 的意味付けが保証され得ることにも言及した。

最近の多目的ダム事業ではレクリエーション目的 や環境対策目的の参入などの新たな展開が期待され ているが，このような事業の環境変化における慣用 法の適用の妥当性についても検証, 判定が求められ る.その上で必要であればSCRB法の補正などの見 直しについての検討が不可欠となってくる.

なお，ここで取り上げた多目的ダム事業のための 費用割振り法に関する理論的知見は，交通整備や都 
市整備の共同事業にも適用が期待される. 事実, 秀 島ら ${ }^{211}$ は都市拠点開発における基盤整備事業を取り 上げて,この種のアプローチの適用可能性を実証し ている．ただし，単に共同事業費の配分だけではな く,開発利益を考慮した総合的な配分を考える方が 妥当な場合もあり，便益の測定法を含めた便益配分 的なアプローチを試行する必要もあろう．また，交 通整備や都市整備には，多くの主体がプレイヤーと して参入する可能性がある。この場合には，ある程 度利害を共通にする主体がグループを形成して，グ ループ間でゲームを演じることも考えられる．この ようにゲームを階層的に構成することにより，いた ずらに膨大な計算を回避することができる．また， 主体間の提携形成の過程をより広範な交渉ゲームと してモデル化し，分析していくことも有効であろう. これらの点については今後の課題としたい.

謝辞：本研究の遂行に当たっては多くの方々や機 関からデータの提供や研究上のアドバイスを賜わっ た. 特に, 東北大学の武藤滋夫先生にはゲーム理論 の御専門の立場から貴重な御示唆をいただいた．付 して，謝辞とします。

\section{付録}

\section{ゲームの費用関数特性}

・劣加法性(Sub-additivity)

共同事業に参加する動機付けとして最も基本的な 条件が劣加法性であり, 次式で表わされる.

$$
C(S)+C(T) \geq C(S \cup T)(\forall S, T \subset N, S \cap T=\varnothing)
$$

劣加法性は， $S$ と $T$ が提携 $S \cup T$ を結んだときの費用 は少なくともそれぞれの提携が独立に事業を行った ときの費用の和を越えないことを保証している．ま た費用差関数 $g(S)$ を用いると, 劣加法性の条件は次 式のようである.

$$
g(S)+g(T) \geq g(S \cup T) \quad(\forall S, T \subset N, S \cap T=\varnothing) \quad(\mathrm{A} .2)
$$

また上式より，次式が成立する．

$$
g(i)+g(S-\{i\}) \geq g(S) \quad(\forall i \in S \subset N)
$$

なお，劣加法性の条件において，等号を含むもの を弱劣加法性, 含まないものを強劣加法性と区別す ることができる.
以下に劣加法性の条件下に, 次の性質を定義する.

- Convex性

Convex性は劣加法性を拡張した条件であり，次式 で表わされる.

$$
C(S)+C(T) \geq C(S \cup T)+C(S \cap T)(\forall S, T \subset N)(\mathrm{A} .4)
$$

費用差関数を用いて表わすとConvex性の必要条件 は次のようになる.

$$
g(S-\{i\}) \leq g(S) \quad(\forall i \in S \subset N)
$$

これは費用差関数 $g(S)$ が提携の規模が大きくなる につれて増加することを表わす，また，限界費用 (marginal cost)MCを以下のように定義する.

$$
M C(S, S-\{i\})=C(S)-C(S-\{i\})
$$

明らかなように, $M C(N, N-\{i\})=S C_{i}$ が成立する. 限界費用を用いると, Convex性の条件は以下の式で 表わされる。

$$
M C(S, S-\{i\}) \leq M C(T, T-\{i\}) \quad(\forall i \in T \subset S \subset N)
$$

- Semi-convex性

任意の部分提携Sに対し，それに含まれる任意の 単独提携 $\{i\}$ を考えると, Semi-convex性が成立すれ ば, $g(i)$ が任意の提携Sに対して最小となる．すなわ ち,

$$
g(S) \geq g(i) \quad(\forall i \in S \subset N)
$$

である. Semi-convex性の十分条件を限界費用を用い ると以下の式で表わされる。この式からもわかるよ うに, Semi-convex性はConvex性を含む集合である.

$$
M C(S, S-\{i\}) \geq M C(N, N-\{i\})=S C_{i} \quad(\forall i \in S \subset N)
$$

- One-convex性

One-convex性が成立すれば，全提携 $N$ 対する $g(N)$ が任意の部分提携

$$
g(S) \geq g(N) \quad(\forall S \subset N)
$$

である. Semi-convex性と同様にOne-convex性の十分 
条件を限界費用を用いて表わすと, 次式のようであ る.

$$
M C(S, S-\{i\}) \leq M C(N, N-\{i\})=S C_{i} \quad(\forall i \in S \subset N)
$$

本論文ではこれらの特性に加え, 以下に示す Weak-convex性を定義した.

- Weak-convex性

Weak-convex性はConvex性を緩めた条件の一つで あり, 次式で表わされる.

$$
g(S) \leq g(N) \quad(\forall S \subset N)
$$

Weak-convex性が成立すれば，全提携 $N$ に対する $g(N)$ が任意の部分提携Sに対して最大となる.この条 件の十分条件を限界費用を用いて表わすと, 次式の ようであるが，これはSemi-convex性の十分条件を限 界費用で表わしたものと同一となる。

$$
M C(S, S-\{i\}) \geq M C(N, N-\{i\})=S C_{i} \quad(\forall i \in S \subset N)
$$

\section{参考文献}

1) Federal Inter-Agency River-Basin Committee, Proposed Practices for Economic Analysis of River Basin Projects, Technical Report, Washington D.C., 1950.

2) 岡田憲夫 : 公共プロジェクトの費用配分法に関する研 究 : その系譜と展望,士木学会論文集, No.431/IV-15,1991.

3) Suzuki,M. and Nakayama,M. : The Cost Assignment of the Cooperative Water Resource Development : A Game Theoretic Approach, Management Sci., Vol.22, pp.1081-1086, 1976.

4) Young,H.P., Okada,N. and Hashimoto,T. : Cost Allocation in Water Resources Development, Water Resour. Res., Vol.18, pp.463-475, 1982.

5) Driesen,T.S.H. and Tijs,S.H. : The Cost Gap Method and Other Cost Allocation Methods for Multipurpose Water Projects, Water Resour. Res., Vol.21, No.10, pp.16491675, October, 1985.
6) 森 統: 費用配分法の考え方, 展望, 日交研シリーズ, A-129, 日本交通政策研究会, pp.1-19,1989.

7) 岡田憲夫, 谷本圭志 : 多目的ダム事業の費用配分法に関 するゲーム論的考察,応用地域科学会発表論文,1993.

8) 佐々木才朗 : 多目的ダムのコストアロケーションに関 する研究,東京大学工学部博士論文,1992.

9) Aumann,R.J.(丸山 徹, 立石 寛訳): ゲーム理論の基 礎, 剄草書房, p.43, 1991.

10) Schmeidler,D : The Nucleolus of a Characteristic Function Game, SIAM, Journal of Applied Mathematics 17, pp.1163-1170, 1969.

11) Maschler,M.,B.Peleg and L.S.Shapley : Geometric Properties of the Kernel, Nucleolus and Related Solution Concepts,Mathematics of Operations Research.4, pp.303-338,1979.

12) L.S.Shapley: Cores of Convex Games, Int. J. Game Theory, Vol. I, pp.11-26, 1971.

13) Heaney,J. and Dickinson,R.E. : Methods for Apportioning the Cost of a Water Resource Project, Water Resour. Res., Vol.18, No.3, pp.476-482, 1982.

14) 鈴木光男 : 費用分担ゲームの解,数理科学,No.256,10月 号,pp.63-68, 1984.

15) 鈴木光男, 中村健二郎 : 社会システム, 共立出版, 1976.

16) Driesen,T.S.H. and Tijs,S.H. : Semi-convex Games and the $\tau$-value, Rep. 8228, Dept. of Math., Catholic Univ., Nijmegen, The Netherlands, 1982.

17) Driesen,T.S.H. : Properties of one-convex $n$-person Games, Oper, Res. Spektrum, Vol.7, pp.19-26, 1985.

18) 岡田憲夫: 費用割り振り問題の理論的考察 一費用関数 の構造に着目して一,鳥取大学工学部研究報告,第21巻, 第1号,pp.203-211，1990.

19) 日本の多目的ダム事業 付表編,建設省河川局監修,ダ ム技術センター発行

20) 谷本圭志 : 新たな目的を加えた費用割振り問題に関す る基礎的研究 一親水目的を対象として一,京都大学修 士論文, 1995 .

21) 秀島栄三, 岡田憲夫, 吉川和広, 塚本敦彦: 都市拠点 開発における基盤整備事業の協力分担方式に関するグ 一么論的考察, 土木計画学研究・論文集 No.11, 1993. 


\title{
A GAME THEORETIC ANALYSIS OF COMMONLY USED COST ALLOCATION METHODS IN MULTI-PURPOSE RESERVOIR DEVELOPMENT FOR METHODOLOGICAL IMPROVEMENTS
}

\author{
Norio OKADA and Keishi TANIMOTO
}

In multi-purpose reservoir developments, a critical question is how to allocate joint costs among its many uses. In Japan, a commonly used method is SCRB(Separable Cost Remaining Benefit) Method. This and other commonly used methods are more useful but less clear in terms of the theory behind the reasoning of the solutions. In recent years, it is becoming more common that a multi-purpose reservoir is required to deal with various needs. Therefore it becomes a problem of whether the commonly used methods, for example SCRB, could be applied to new situations such as a multi-purpose reservoir. This paper presents the applicability of the conditions of the commonly used methods in terms of game theory. 